Bangladesh J. Plant Taxon. 19(1): 79-84, 2012 (June)

(C) 2012 Bangladesh Association of Plant Taxonomists

\title{
THREE NEW SPECIES OF CURCUMA L. (ZINGIBERACEAE) FROM BANGLADESH
}

\author{
M. Atiqur RAHMAN ${ }^{1}$ and M. YusuF ${ }^{2}$ \\ Department of Botany, University of Chittagong, Chittagong 4331, Bangladesh
}

Keywords: New species; Zingiberaceae; Curcuma roxburghii; C. wallichii; C. wilcockii; Bangladesh.

\begin{abstract}
Three new species of the Section Masantha Horan. of the genus Curcuma L. (Zingiberaceae), viz., C. roxburghii Rahman et Yusuf, C. wallichii Rahman et Yusuf and C. wilcockii Rahman et Yusuf from Bangladesh are described and illustrated. These species were collected from the forests of Rangamati, Moulvi Bazar, Sylhet and Tangail districts. Diagnostic morphological characters from closely related taxa are discussed. A key to the Bangladesh species of Section Masantha Horan. is presented.
\end{abstract}

\section{Introduction}

In course of the study on the Zingiberaceae for its complete inventory for the Flora of Bangladesh we have made an extensive survey throughout the country and collected a number of specimens of the family during the period from 1993 to 2000. During our field trips we have recognized the occurrence of two distinct groups of Curcuma L. in the wild; one group with the spikes lateral to the leafy shoots belonging to Section Exantha Horan. and the other group with the spikes terminal on the leafy shoots belonging to Section Masantha Horan. Survey of the relevant literature of Roxburgh (1814, 1820, 1832), Wallich (1829-49), Baker (1890), Prain (1903), Heinig (1925), Kanjilal et. al. (1934), Raizada (1941), Sinclair (1956), Rahman (1995), Rahman and Yusuf $(1996,1997)$ showed that, the genus Curcuma is represented in the flora of Bangladesh by nine species of which two species, C. amada Roxb. and C. longa L. belong to the Section Masantha Horan. On the other hand, remaining seven species belong to the Section Exantha Horan., and these are C. amarissima Rosc., C. aromatic Salisb., C. caesia Roxb., C. ferruginea Roxb., C. latifolia Rosc., C. rubescens Roxb., and C. zedoaria (Christm.) Rosc.

During field trips we came across some characteristically distinct flowering populations of Curcuma with terminal spikes growing in the forest floors of Rangamati (one of the Chittagong Hill Tract districts), Lawachara rain forest (Moulvi Bazar district), forest of Tamabil hills (Sylhet district) and Madhupur Sal forest (Tangail district) which hitherto represent undescribed species of the Section Masantha Horan. The flowering specimens were collected and preserved for identification. The rhizomes were also collected and grown in the field of Bangladesh Council of Scientific and Industrial Research (BCSIR), Chittagong and in the Botanic Garden of Chittagong University. The specimens were critically examined and compared with the identified specimens of Curcuma L. available at CAL, BM, DACB, E, K, BCSIRH, DUSH (Dhaka University Salar Khan Herbarium) and HCU (Herbarium of Chittagong University) and finally confirmed them as three new species in Section Masantha Horan. of the genus Curcuma L. These new species are similar to C. amada Roxb. and C. longa L. belonging to the same Section but characteristically different from each other for a number of variations in floral structures, leaf morphology and in shape and colour of rhizomes.

\footnotetext{
${ }^{1}$ Corresponding author. Email: atiquerahman125@hotmail.com

${ }^{2}$ Bangladesh Council of Scientific and Industrial Research, Chittagong, Bangladesh.
} 
Curcuma wilcockii Rahman et Yusuf is distinct from other species of the Section for its orange-yellow flowers, anthers without spur and indistinct colour of coma and fertile bracts. $C$. roxburghii Rahman et Yusuf is distinct for its exserted flowers and turmeric smell of rhizomes. $C$. wallichii Rahman et Yusuf, on the other hand, is distinct for its non-exserted flowers, purplish pink coma bracts and hairy ovary. Hence, the Section Masantha Horan. recognized here to be representing in the flora of Bangladesh by five species including these three new species. A key to these five taxa are presented. The new species are described with Latin diagnosis. Illustrations with photographs of habits are provided.

\section{Key to the species:}

1. Coma and fertile bracts indistinct in colour; flowers orange-yellow; anthers without spur; main rhizome without horizontal branches.

- $\quad$ Coma and fertile bracts distinct in colour; flowers not orange-yellow; anthers with spur; main rhizome with horizontal branches.

2. Flowers exserted, longer than bracts.

Flowers not exserted, more or less equal to the bracts.

3. Base sheaths green; lamina puberulous on the upper side; coma bracts pinkish or whitish; fertile bracts pale green; rhizomes pale yellow with smell of green mango; ovary villous throughout.

- $\quad$ Base sheaths purple; lamina glabrous on both sides; coma bracts light purple, white at base; fertile bracts light green with purple edges; rhizomes yellow with light smell of turmeric; ovary hairy at the top only.

4. Coma bracts greenish or white with purplish tips; fertile bracts light green; staminodes up to $12 \mathrm{~mm}$ long, ligulate, creamy white; labellum oblong, $15 \mathrm{~mm}$ long; ovary hairy at the top.

- $\quad$ Coma bracts purplish pink; fertile bracts light green, pinkish on the apical border; staminodes $16 \mathrm{~mm}$ long, oblong, light yellow; labellum obovate, $20 \mathrm{~mm}$ long; ovary hairy throughout.

\section{C. wilcockii}

4

\section{C. amada}

C. roxburghii

C. longa

C. wallichii

1. Curcuma roxburghii Rahman et Yusuf, sp. nov.

(Fig. 1)

Diagnosis: Curcuma roxburghii distinctus per floribus extrusus, rhizomatibus turmericodorem.

Holotypus: Bangladesh, Rangamati district, Rangapani, 8.7.1993, M. Yusuf et M.A. Rahman 803 (BCSIRH).

Rhizomes large, bright yellow inside with light turmeric smell. Leaf tufts 1.2-1.5 m long; base sheaths of young shoots green, suffused with purple. Leaves 5-7, suberect, lamina broadly lanceolate, acuminate at apex, cuneate at base, 55-85 × 17-21 cm, glabrous, green throughout; petioles 20-35 cm long. Spikes central to the leaf tufts, $16-19 \times 5 \mathrm{~cm}$; fertile bracts $12-14$, light green with purple edges, 3.5-3.8 $\times 2.8 \mathrm{~cm}$, obovate, obtuse, apex and base sparsely hairy, adnate to each other half way or more in the lower portion, each subtending 3-4 flower buds; coma bracts 811, light purple, white at base, sub-elliptic, 6.1-6.5 × 3.3-3.8 cm, obtuse, mucronate, hairy at apex; bracteoles obovate, 2.2-2.5 $\times 1.5-2.0 \mathrm{~cm}$, white with pinkish tips, glabrous. Flowers much exserted at the lower bracts. Calyx white, c. $1 \mathrm{~cm}$ long, 3-lobed, hairy on the nerves. Corolla tube c. $3 \mathrm{~cm}$ long, light yellow; petals 3 , white, glabrous, lateral two ovate, rounded at apices, upper one 
hooded, spured at apex. Staminodes obliquely ligulate, $12 \times 10 \mathrm{~cm}$, creamy white; labellum broadly obovate with emerginate beak, c. $15.0 \times 16.5 \mathrm{~mm}$, creamy with yellow mid band; filaments broad, flat, $4.0 \times 3.5 \mathrm{~mm}$; anthers c. $3.5 \mathrm{~mm}$ with two $2.5 \mathrm{~mm}$ long basal spurs. Ovary white, hairy, $3.5 \times 2.5 \mathrm{~mm}$; epigynous glands c. $4 \mathrm{~mm}$ long.
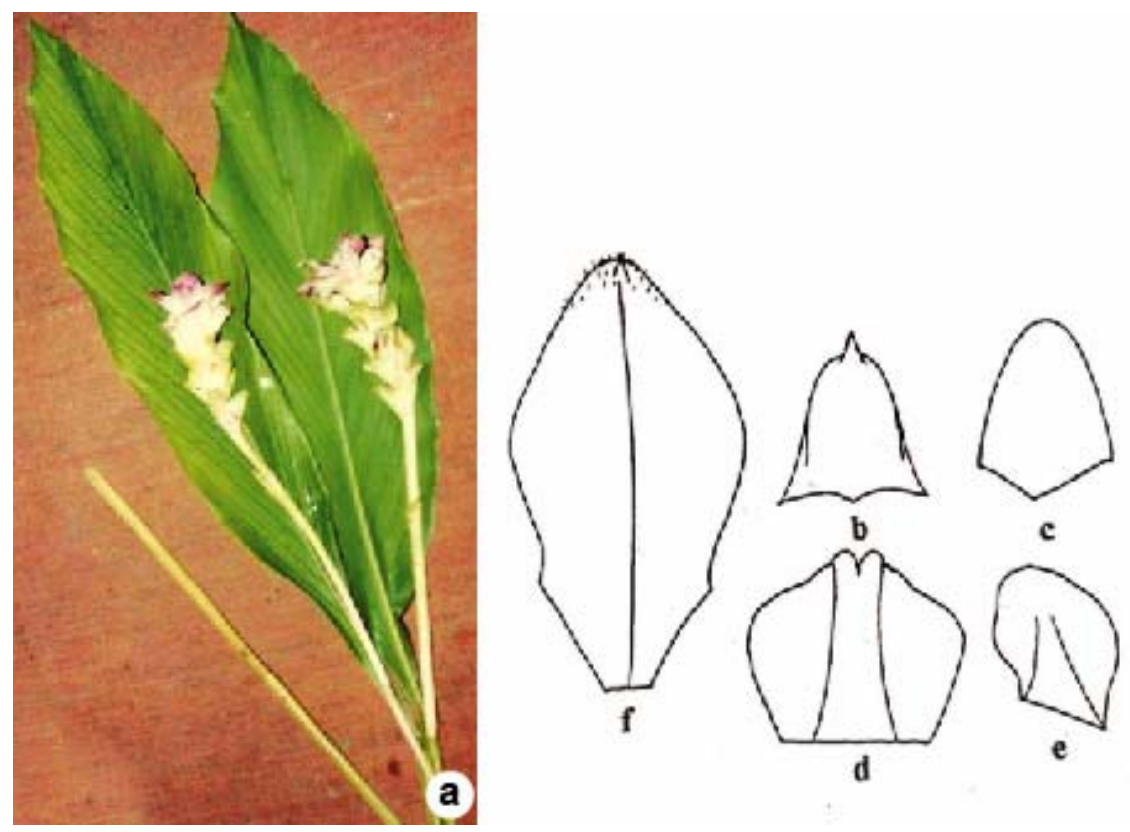

Fig. 1. Curcuma roxburghii sp. nov.: a. habit of the plant with inflorescences (photograph); b. dorsal petal ( $\times$ 1.6); c. lateral petal $(\times 1.6)$; d. labellum $(\times 1.6)$; e. staminode $(\times 1.6)$; f. coma bract (largest one) $(\times 0.7)$.

Phenology: Flowering in July-August.

Specimens examined: Rangamati: Rangapani, 8.7.1993, M. Yusuf \& M.A. Rahman 803 (BCSIRH: holo!), 803 b (HCU) and 803 b (DACB); ibid, 18.7.1998, M. Yusuf 1053 (BCSIRH) and 1054 (DACB).

Distribution: South-eastern part of the flora of Bangladesh, Rangamati district (one of the Chittagong Hill Tracts districts of Bangladesh). Endemic.

Ecology: Grows on the hill slopes in partial shade, at about $570 \mathrm{~m}$ altitude.

Conservation status: It is known from the type locality only. Few populations were seen at the type locality. It can be graded as LR (cd) category (IUCN, 1994).

Etymology: This species is named in honour of Dr. William Roxburgh, father of Indian Botany, who has made outstanding contribution in collecting and naming most of the plants of the then Bengal.

Note: It is closer to C. amada Roxb. for exserted flower, distinct colour of fertile and coma bracts and spured anthers but differs for purple base sheaths, glabrous lamina, purple coma bracts, light green with purple edged fertile bracts and turmeric smelled yellow rhizomes. 
2. Curcuma wallichii Rahman et Yusuf, sp. nov.

(Fig. 2)

Diagnosis: Curcuma wallichii distinctus per floribus intrusus, coma bracteis purpureuspersinus, ovarium puberulus.

Holotypus: Bangladesh, Maulvi Bazar district, Srimangal, Lawachara forest, 16 July, 1993, M. Yusuf et M.A. Rahman 813 (BCSIRH).

Rhizomes light yellow inside. Leaf tufts $1 \mathrm{~m}$ long, base sheaths green. Leaves 6-7, spreading, lamina elliptic, acuminate, 66-70 × 21-24 cm, glabrous, green throughout; petioles 8-14 cm long. Spikes central to the leaf tufts, $18-20 \times 8 \mathrm{~cm}$; fertile bracts up to 24, light green, pinkish on the apical boarder, each subtending 4-6 flower buds; coma bracts up to 11, large, elliptic-oblong, obtuse, c. $8.5 \mathrm{~cm}$ long, purplish pink, hairy; bracteoles white, c. $3.0 \times 1.8 \mathrm{~cm}$, ovate, folded, apex sparsely hairy on the main nerves. Flowers slightly exserted at the lower bracts and included at the upper bracts. Corolla tube light yellow, c. $3.2 \mathrm{~cm}$ long; lobes white, glabrous, dorsal one hooded apical, $1.6 \times 1.2 \mathrm{~cm}$. Staminodes light yellow, obliquely oblong, c. $16 \times 9 \mathrm{~mm}$; labellum broadly obovate, 3-lobed, apex emarginate, yellow with deep yellow mid band; filaments c. $3.5 \times 3.8 \mathrm{~mm}$; anthers $4 \mathrm{~mm}$ long with two $3 \mathrm{~mm}$ basal spurs. Ovary white, hairy, $4.5 \times 3.5 \mathrm{~mm}$; epigynous glands yellow, 4.0-4.5 mm long.

Phenology: Flowering in July.

Specimen examined: Maulvi Bazar: Srimangal, Lawachara rain forest, 16.7.1993, M. Yusuf \& M.A. Rahman 813 (BCSIRH: holo!).

Distribution: Eastern part of the flora of Bangladesh, Maulvi Bazar district (within greater Sylhet). Endemic.

Ecology: Grows in the rain forest area in partial shades.
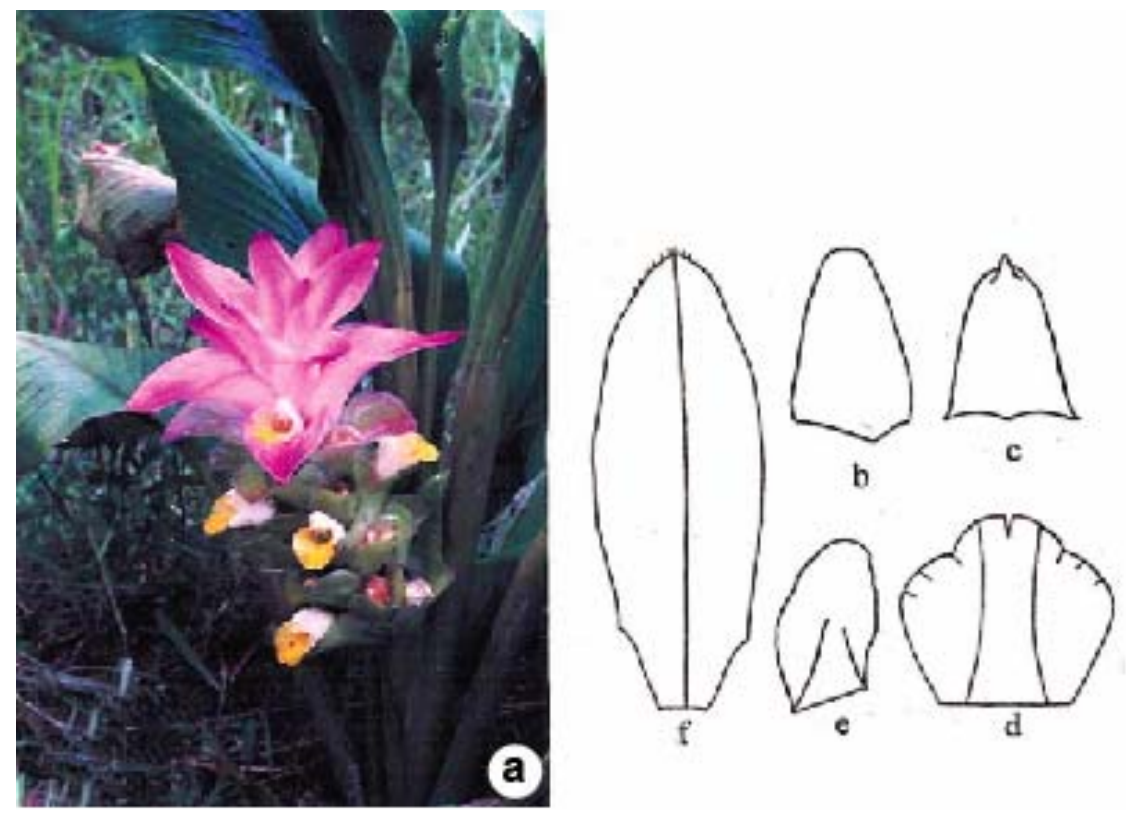

Fig. 2. Curcuma wallichii sp. nov.: a. habit of the plant with inflorescences (photograph); b. lateral petal $(\times 1.4)$; c. dorsal petal $(\times 1.4) ;$ d. staminode $(\times 1.4)$; e. labellum $(\times 1.4) ;$ f. coma bract (largest one) $(\times 0.8)$. 
Conservation status: It is known from the type locality only. A few populations were seen at the type locality. It can be graded as LR (cd) category (IUCN, 1994).

Etymology: It is named in honour of Dr. Nathaniel Willich, superintendent of the then East Indian Company's Museum, Calcutta, who has collected and named a huge number of plants from the Indian subcontinent including the area now in Bangladesh.

Note: It is closer to C. longa L. for included flowers, distinct colour of fertile and coma bracts and spured anthers but differs for purplish pink coma bracts, light green fertile bracts, light yellow longer staminodes and hairy ovary.

3. Curcuma wilcockii Rahman et Yusuf, sp. nov.

(Fig. 3)

Diagnosis: Curcuma wilcockii distinctus per floribus aurantiacus-flavidis, antheris sine calcaris, coma et fertilis-bracteis coloris indistinctus.

Holotypus: Bangladesh, Tangail district, Madhupur sal forest, Rasulpur, 21 August, 1993, M. Yusuf et M.A. Rahman 838 (BCSIRH).

Rhizomes small without horizontal branch, white inside, strongly aromatic. Leaf tufts c. 60 cm long. Leaves 6-7, spreading, lamina ovate, acuminate, 39-43 × 13-17 cm, deep green, glabrous, lateral veins raised; petioles $12-16 \mathrm{~cm}$ long. Spikes central to the leaf tufts; peduncles $16-20 \mathrm{~cm}$; spikes c. 15-20 × 8-9 cm; bracts many, 60-70 in number, green, c. $5 \times 3 \mathrm{~cm}$; coma and fertile bracts indistinct; lower bracts with rusty tinge, minutely hairy, tips out-curved; bracteoles oblong, c. $10 \times 6 \mathrm{~mm}$, white, apex and mid-veins hairy. Flowers orange-yellow, usually not exserted except slightly at the lower bracts. Calyx white, hairy, 3-lobed, c. 16-17 mm long. Corolla orangeyellow, tube c. 3.0-3.5 cm long; lower 2 lobes oblong, tip rounded, c. 18-19 × 8-10 mm, glabrous;
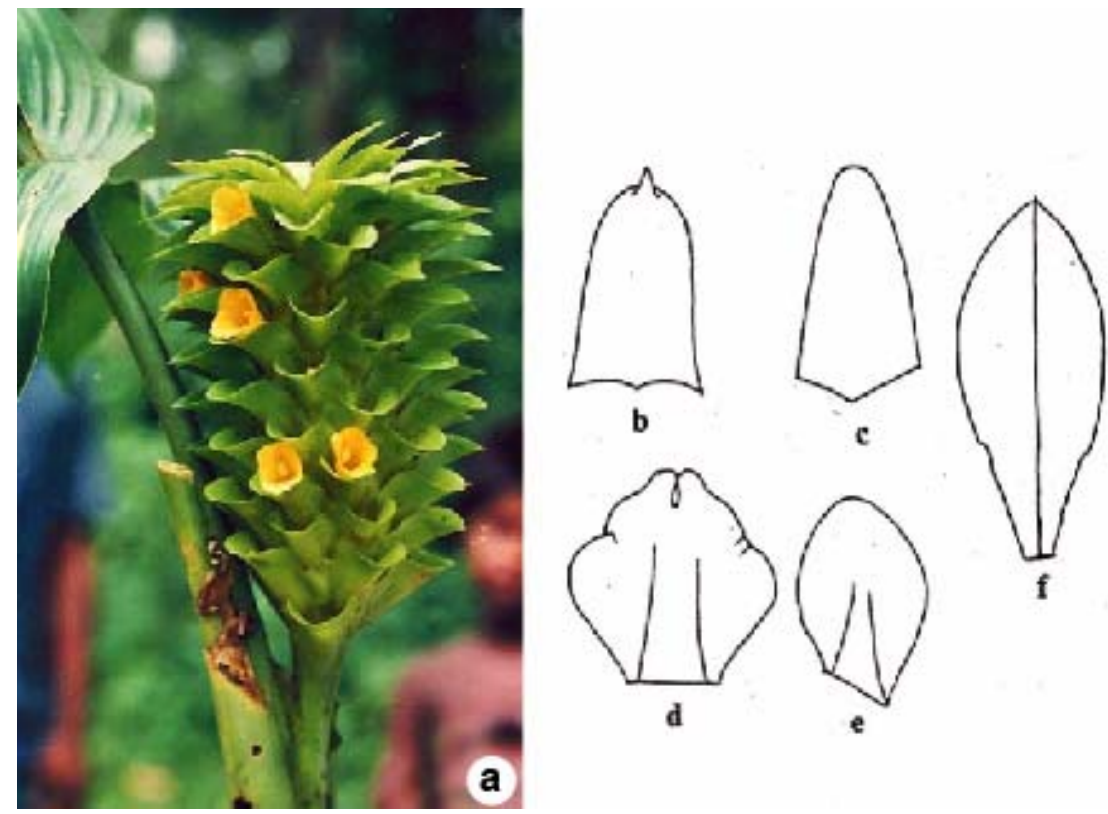

Fig. 3. Curcuma wilcockii sp. nov.: a. habit of the plant with inflorescences (photograph); b. dorsal petal $(\times 1.6)$; c. lateral petal $(\times 1.6) ;$ d. labellum $(\times 1.6)$; e. staminode $(\times 1.6)$; f. coma bract (largest one) $(\times 0.8)$. 
upper lobe oblong, hooded, apiculate, 18-19 × 8-12 mm, hairy. Staminodes obovate, c. $16 \times 10$ $\mathrm{mm}$, orange-yellow, margins ciliate; labellum obscurely 3-lobed, emarginate, apex ciliate, orangeyellow; filaments flattened, $2 \times 3 \mathrm{~mm}$; anthers without spur, cells curved with curved crest. Ovary $2 \times 2 \mathrm{~mm}$, hairy; stigma c. $1.3 \mathrm{~mm}$ broad, not exserted; epigynous glands 4.0-4.5 mm long, free.

Phenology: Flowering in August-September.

Specimens examined: Tangail: Madhupur sal forest, Rasulpur, 21.8.1993, M. Yusuf \& M.A. Rahman 838 (BCSIRH: holo!); ibid, 23.7.1994, M. Yusuf \& M.A. Rahman 896 (BCSIRH); ibid, 22.7.1997, M. Yusuf \& M.A. Rahman 1000 (HCU). Sylhet: Tamabil, 9.9.1995, M. Yusuf \& M.A. Rahman, 904 (BCSIR); ibid, 18.9.1996, M. Yusuf \& M.A. Rahman, 965 (HCU); ibid, 4.9.1997, M. Yusuf \& M.A. Rahman, 1016 (DACB).

Distribution: Central and eastern parts of Bangladesh (Tangail and Sylhet districts).

Ecology: Grows in dry moist forest floors.

Conservation status: It has been collected from two localities. A few populations were seen at both localities. It can be graded as LR (cd) category (IUCN, 1994).

Etymology: It is named in honour of Dr. Christopher C. Wilcock of Aberdeen University (Department of Plant and Soil Science) for his involvement with the Flora of Bangladesh Project for long time and outstanding contribution to the Taxonomy and Biodiversity of Bangladesh.

Note: It is closer to $C$. longa L. for its included flowers but differs for indistinct colour of fertile and coma bracts, orange-yellow flowers and anthers without spur.

\section{Acknowledgement}

The authors are grateful to the authorities of the CAL, E, K, DACB and DUSH for providing facilities to study their materials and to consult their libraries.

\section{References}

Baker, J.G. 1890. Scitamineae. In: Hooker, J.D., Flora of British India 6: 198-257. Reeve \& Co. England.

Heinig, R.L. 1925. List of plants of Chittagong collectorate and Hill Tracts. Darjeeling, 84 pp.

IUCN 1994. Red List Categories. Gland, Switzerland: IUCN Species Survival Commission.

Kanjilal, U.N., Kanjilal, P.C., and Das, A. 1934. Flora of Assam, Vol. 1. Government of Assam, Shillong.

Prain, D. 1903. Bengal Plants 2: 262-273. (Reprint ed.1981).

Rahman, M.A. 1995. An index of Wallich material of Zingiberaceae, Costaceae and Marantaceae from Bangladesh held in Herb. Wall (K-W). Bangladesh J. Plant Taxon. 2(1\&2): 1-5.

Rahman, M.A. and Yusuf, M. 1996. Diversity, ecology and ethnobotany of the Zingiberaceae of Bangladesh. J. Econ. Taxon. Bot. Add. Series 12: 13-19.

Rahman, M.A. and Yusuf, M. 1997. New records of Zingiberaceae for Bangladesh. Bangladesh J. Bot. 26(1): $1-5$.

Raizada, M.B. 1941. On the flora of Chittagong. The Indian Forester 67: 245-267.

Roxburgh, W. 1814. Monandria Monogynia. Hortus Bengalensis (num. nud.), pp. 1-2.

Roxburgh, W. 1820. Monandria Monogynia. Flora Indica, ed. Carey.

Roxburgh, W. 1832. Monandria Monogynia. Flora Indica, ed. Carey.

Sinclair, J. 1956. The Flora of Cox’s Bazar. Bull. Bot. Soc. Beng. 9(2):84-116.

Wallich, N. 1829-49. A numerical list of dried specimens of plants in the East Indian Company's Museum. 